\title{
PENDAMPINGAN PERHITUNGAN MAWARIS DENGAN APLIKASI ANDROID PADA PENGURUS DAN JAMAAH MASJID PARIPURNA AL MUHAJIRIN PEKANBARU
}

\author{
Guntoro ${ }^{1)}$, Lasri Nijal ${ }^{2)}$ \\ ${ }^{1)}$ Prodi Teknik Informatika, Fakultas Ilmu Komputer, Universitas Lancang Kuning, e-mail: guntoro@unilak.ac.id \\ ${ }^{2)}$ Prodi Sistem Informasi, Fakultas Ilmu Komputer, Universitas Lancang Kuning, e-mail: lasrinijal@unilak.ac.id
}

\begin{abstract}
Abstrak
Masjid selain tempat untuk ibadah juga berfungsi untuk menimba ilmu dengan para ustad maupun ustazah dengan dijadwalkan oleh pengurus masjid. Masjid al muharin yang terletak di jalan Umban sari atas Kecamatan Rumbai termasuk masjid paripurna yang dinilai sangat baik oleh pemerintah kota pekanbaru. Diantara permasalahan yang banyak terjadi adalah berkenaan dengan hak waris, rasa ego dan nafsu manusia membuat banyak anggota keluarga gelap mata tanpa perdulikan perasaan kekeluargaan. Mengatasi permasalahan tersebut perlunya melakukan pendampingan pelatihan mawaris dengan menggunakan aplikasi Android bagi pengurus dan jamaah Masjid paripurna Al Muhajirin Pekanbaru. Adapun tahapan pendampingan ini adalah melakukan pretest, pelatihan, evaluasi dan posttest. Hasil dari pendampingan yang telah dilakukan menunjukkan, bahwa tingkat pemahaman masyarakat tentang penghjitungan mawaris masih rendah yaitu sebesar $17.0 \%$, Setelah mengikuti pendampingan, terjadi kenaikan pemahaman peserta dalam melakukan pelatihan sebesar $76.0 \%$, sehingga tingkat pemahaman peserta meningkat sebesar $93.0 \%$,
\end{abstract}

Kata Kunci: Android, Mawaris, Pendampingan

\begin{abstract}
Apart from being a place of worship, the mosque also functions to gain knowledge of ustads and ustazahs, which are planned by the management of the mosque. Al Muharin Mosque, located on Umban Sari Street above the Rumbai District, is a complete mosque considered very good by the Pekanbar City Government. Among the problems that often occur are with regard to inheritance rights, the sense of ego and human desire makes many family members have dark eyes regardless of family feelings. Overcoming these problems, Mawaris training assistance must be provided through the use of an Android application for the Al Muhajirin Pekanbaru Mosque administrators and congregations. The stages of this assistance shall be pre-test, training, evaluation and post-test. The results of the assistance provided show that the level of understanding of the community in calculating the Mawaris is still low at 17\%. After participating in mentoring, the level of understanding of the participants increased to $93 \%$ and because the level of understanding of the participants in training increased $76 \%$.
\end{abstract}

Keywords: Android, Mawaris, Training

\section{PENDAHULUAN}

Setiap muslim sangat dianjurkan untuk beribadah kepada sang maha pencipta, seorang pria sangat dianjurkan untuk sholat dimasjid dan wanita juga tidak dilarang untuk beribadah dimasjid (Mochammad Arif Budiman \& Mairijani, 2016). Masjid selain tempat untuk ibadah juga berfungsi untuk menimba ilmu dengan para ustad maupun ustazah dengan dijadwalkan oleh pengurus masjid. Tekadang juga masjid sering dijadikan untuk menyelesaikan permasalahan sosial masyarakat secara umum hingga ruang lingkup keluarga (Mulyono, 2011).

Masjid al muharin yang terletak di jalan Umban sari atas Kecamatan Rumbai termasuk masjid paripurna yang dinilai sangat baik oleh pemerintah kota pekanbaru. Sehingga diurus oleh orang orang yang amanah sebagai tokoh yang dihormati oleh masyarakat dan jamaah dilingkungan masjid. 


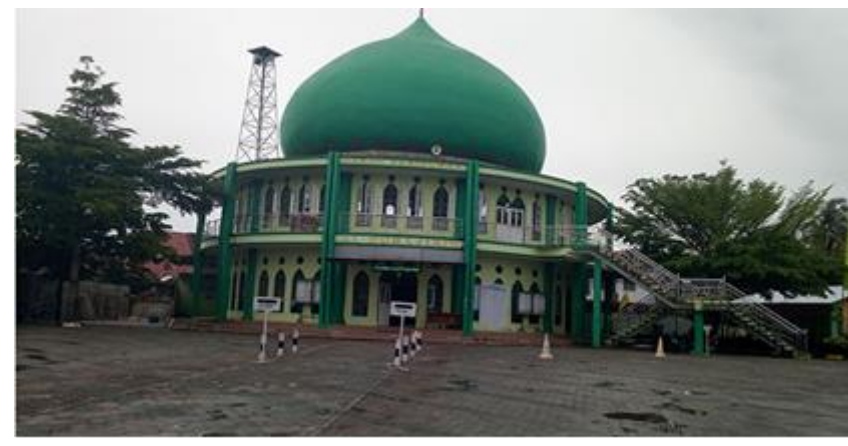

Gambar 1. Masjid Al Muhajin

Sebelumnya ketua Masjid Paripurna Al Muhajirin di pimpin oleh Abu Kasim SAg, dengan berbagai capaian yang telah diwujudkan selama masa memimpin, membuat masjid selalu aktif dalam berbagai kegiatan keislaman. Saat ini kepemimpinan dilanjutkan H Syahril, SPd untuk masa jabatan 2019 $-2024$.

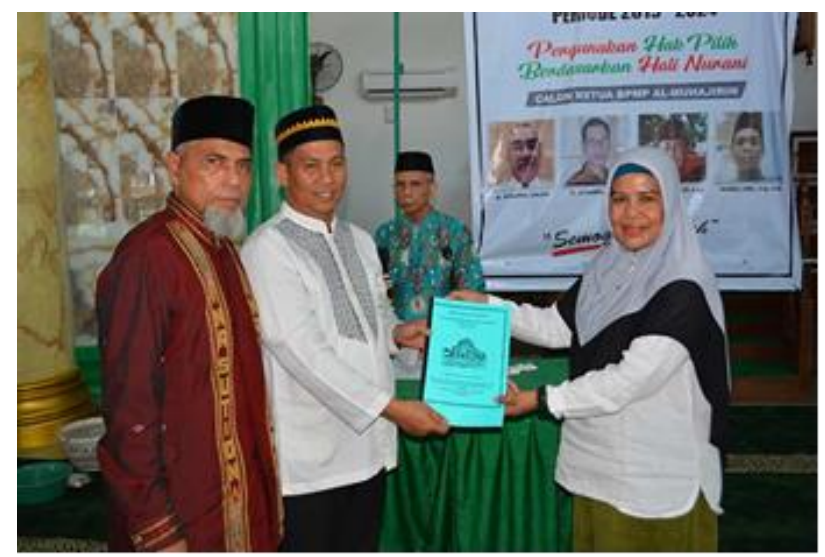

Gambar 2. Serah terima terpilihnya ketua masjid paripurna Al Muhajirin

Aktifnya sebuah masjid akan membuat jamaah semakin ramai, pengurus yang amanah akan membuat jamaah nyaman dan merasa tenang setiap melakukan aktifitas ibadah, hal ini tidak terlepas dari leadership pemimpinnya yang selalu berusaha untuk memberikan pelayanan terbaik untuk umat (Huda, Fuady, \& Muhadi, 2020). Peran masjid juga dapat memberikan pemahaman ilmu agama kepada masyarakat sehingga dapat memberikan pencerahan dari kegundahan dalam keluarga masyarakat (Darmawiyah, 2017) .

Keluarga adalah unit terkecil dari sebuah masyarakat yang terdiri dari kepala keluarga dan anggota keluarga baik ibu dan anak-anak. Jika hubungan keluarga ini tidak harmonis tentu berakibat pada perpecahan, permusuhan dan bahkan pembunuhan, ini tentu akan membuat sebuah lingkungan masyarakat menjadi tidak baik (Wahyuni, 2018).

Diantara permasalahan yang banyak terjadi adalah berkenaan dengan hak waris, rasa ego dan nafsu manusia membuat banyak anggota keluarga gelap mata tanpa perdulikan perasaan kekeluargaan. Padahal dalam agama aturan dalam waris sudah diatur sedemikian rapi (Mannuhung, Tenrigau, \& D, 2018). Namun dikarenakan ketidak pemahaman keluarga dan masing masing pihak tentang ilmu dan cara perhitungannya membuat akhir dari perkara tersebut menjadi pertengkaran keluarga besar . Disatu sisi beberapa keluarga yang memiliki permasalahn yang sama sering meminta pendapat dan jalan keluar dari pengurus masjid yang dianggap tokoh oleh masyarakat, padahal kita tau tidak semua struktur pengurus masjid berlatar belakang agama dan paham seluk beluk kerkenaan dengan mawaris. Dengan demikian adanya ilmu tentang mawaris dan cara perhitungan melalui aplikasi android sangat dibutuhkan oleh pengurus masjid dan jama'ah dilingkungan masjid (Loneli Costaner, Bayu Febriadi, \& Guntoro, 2020) (Ismanto, Novalia, \& Herlandy, 2017). Dibekali modul yang siapkan secara grafis dan instalasi aplikasi mawaris diharapkan mampu memberikan solusi terbaik untuk menyelesaikan permaslahan keluarga pada masyrakat muslim (Suryadi, Nasution, \& Febrianti, 2018).

\section{METODOLOGI PENGABDIAN}

Adapun tahapan pengabdian yang dilakukan adalah Menganalisis khalayak sasaran , merancang prosedur kerja, menganalisis kebutuhan dan melakukan implementasi kegiatan.

1. Khalayak Sasaran

Sasaran kegiatan ini adalah pengurus masjid dan jamaah dilingkungan Masjid almuhajirin dengan kriteria peserta yang telah ditentukan, sehingga kegiatan dalam berjalan dengan lancar(Guntoro, Lisnawita, \& Sadar, 2019).

2. Prosedur Kerja.

Sosialisasi dan pelatihan dilakukan dengan mengikuti prosedur agar pelaksanan dapat dilakukan dengan baik, sebagaimana berikut ini:

a. Mengusulkan kegiatan Pengabdian Kepada Masyarakat ke LPPM. 
b. Mengurus dan menyiapkan segala kebutuhan administrasi.

c. Mengirim surat kerjasama untuk melaksanakan kegiatan ditempat mitra pengabdian.

d. Menyiapkan modul pelatihan.

e. Melakukan sosialisasi dan pelatihan menggunakan aplikasi mawaris berbasis android.

f. Melakukan evaluasi terhadap keberhasilan Pengabdian Kepada Masyarakat.

3. Perlengkapan yang dibutuhkan.

Dalam melakukan pelatihan pemanfaatan smartphone android tentu membutuhkan beberapa perlengkapan demi kelancaran yang diharapkan. Perlengkapan yang dibutuhkan sebagai berikut:

a. Spanduk pelatihan atau banner guna menanamkan mindset tentang pelatihan yang akan dilaksanakan, sehingga peserta lebih bersemangat untuk menggikuti pelatihan

b. Quisioner pre test yang berguna untuk mengetahui sejauh mana peserta telah memahami ruanglingkup smartphone sebagai dsain grafis media informasi yang professional.

c. Setiap peserta harus membawa smartphone android yang memiliki kapasistas untuk menginstal aplikasi mawaris.

d. Mitra menyiapkan infocus untuk menampilkan materi dan perhitungan kepada masyarakat.

e. Laptop sebagai persentasi materi kepada peserta.

f. Absensi peserta untuk mengetahui jumlah peserta yang berpartisipasi.

g. Form post test guna mengevaluasi hasil penelitian yang telah dilakukan oleh peserta pelatihan.

h. Poster pelatihan yang berguna menambah informasi tentang pelatihan yang dilaksanakan.

4. Metode pelaksanaan.

Adapun metode pelaksanaan pengabdian ini dijelakan pada bagan yang terlampir, sedangkan tahapan metode tersebut dapat dilihat pada uraian dibawah ini.

a. Observasi, melakukan survei dilapangan, hal ini dilakukan untuk mendapatkan gejala gejala kondisi mitra yang menggangu aktifitas system kehidupan keluarga dan juga ditengah tengah masyarakat.

b. Data, Fakta yang terjadi pada kegiatan mitra, sehingga kendala kendala yang dihadapi dapat selesai dengan baik dan cepat. Kedala yang dihadapi oleh mitra dengan cara memberikan pelatihan kepada pengurus dan jamaah masjid.

c. Solusi, melakukan analisis terhadap kendala atau keresahan yang tejadi dilingkungan masjid almuhajirin, yaitu dibutuhkan pelatihan perhitungan mawaris berbasis android.

d. Preetest, sebelum melakukan pelatihan tim menyebarkan form quisioner sebagai alat ukur tingkat pemahaman berkenaan dengan mawaris dan android.

e. Pelatihan, setiap peserta akan diberikan modul praktek bagaimana memahami mawaris, cara menghitung mawaris dan aplikasi mawaris android.

f. Evaluasi, peserta akan diuji dengan pemahaman dan kemampuannya dalam menghitung mawaris berbasis android dengan cara diberikan kasus ahli waris dengan harta waris yang ditinggalkan oleh pemilik harta.

g. Posttest, peserta yang sudah mendapatkan pelatihan dan sudah menyelesaikan pengujian kasus mawaris akan mengisi form evaluasi guna mengetahui tingkat pemahamannya sebagai indikator keberhasilan dalam pelatihan yang telah dilakukan.

\section{HASIL DAN PEMBAHASAN}

Pelaksanaan kegiatan pengabdian ini dilakukan untuk meningkatkan pemahaman masyarakat baik pengurus dan jamaah masjid dilingkungan Masjid $\mathrm{Al}$ Muhajirin, pelatihan yang dilakukan selama 2 bulan dimulai pada bulan Oktober sampai dengan bulan Nopember 2020. Peserta yang mengikuti sangat antusias dengan tingkat kehadiran konsisten antara 10 hingga 25 orang. Berdasarkan keresahan masyarakat dan pengurus masjid dalam menghadapi persoalan masyarakat sehingga diperlukan edukasi dan pelatihan tentang mawaris berbasis android, berikut hasil yang didapatkan tim pengabdi. 


\section{Pretest}

Sebagaimana langkah awal tim dalam melakukan pengabdian, dimana peserta wajib mengisi form quisioner pemahaman awal sebelum dilakukan pelatihan. Form quisoner yang dimakud adalah pertanyaan berkenaan dengan pemahaman prihal menghitung harta waris, menghitung waris dan membagi kepada ahli waris dengan android.

\section{Pendampingan}

Peserta yang mengikuti pendampingan akan diberikan modul sebagai sarana belajar menghitung mawaris berbasis android. Berikut foto foto proses pelatihan mawaris.

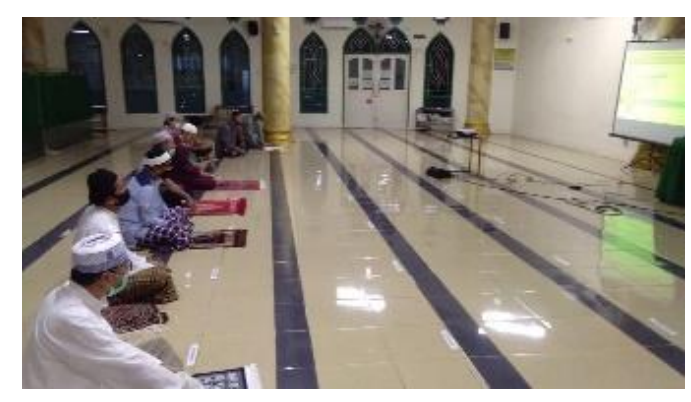

Gambar 5. Tim memberikan pendampingan

\section{Evaluasi}

Peserta mengerjakan latihan perhitungan mawaris dengan kasus sebuah keluarga yang memiliki 4 anggota keluarga, ayah, ibu, 1 anak laki laki dan 1 anak perempuan.

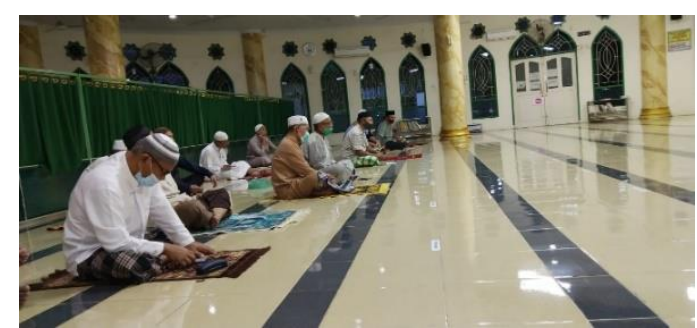

Gambar 7. Peserta mengerjakan perhitungan mawaris

\section{Posttest}

Setelah peserta selesai mengerjakan kasus kasus dalam waris, selanjutkan peserta mengisi form posttest yang berisi 10 pertanyaan pertanyaan yang berkaitan dengan pemahaman sejauh mana peserta sudah mengenal dengan mawaris, menghitung ahli waris dengan aplikasi android.

Setelah peserta mengikuti seluruh tahapan pelatihan, tim pengbadian akan melakukan pengukuran tingkat pemahaman peserta pelatihan berdasarkan quisioner pretest dan posttest dengan menggunakan skala guttman. Skala Guttman tradisional adalah penelitian bila ingin mendapatkan jawaban yang tegas terhadap suatu permasalah ditanyakan, dan selalu dibuat dalam pilihan ganda yaitu "ya dan tidak", "benar dan salah", "positif dan negative", untuk penilaian jawaban misalnya untuk jawaban positif diberi skor 1 sedangkan jawaban negative deberi skor 0 dengan demikian bila jawaban dari pertanyaan adalah setuju diberi skor 1 dan tidak setuju diberi skor 0 bila skor dikoversikan dalam persentase maka secara logika dapat dijabarkan untuk jawaban setuju skor $1=1 \times 100 \%=100 \%$, dan tidak setuju diberi skor $0=0 \times 0 \%=0 \%$.

Pada prakteknya hasil pengukuran sering ditemukan tidak $0 \%$ atau 100\%, maka untuk memudahkan memberikan penilaian secara operasional maka digunakan rentang skala persentase antara $0 \%$ sampai $50 \%, 50 \%$ dan $50 \%$ sampai $100 \%$ sebagai contoh hasil pengukuran 20\% maka ditempatkan pada rentang $0 \%$ sampai $50 \%$, bila hasil pengukuran $50 \%$ maka ditempatkan pada $50 \%$ sedangkan bila hasil pengukuran $70 \%$ maka ditempatkan pada rentang 50\% sampai $100 \%$

\section{Hitung tingkat pemahaman}

Pada pengabdian ini diikuti lebih kurang sebanyak 20 orang, dan mengisi quisoner yang lengkap sebanyak 10 orang pretest dan posttest seperti di tabel 1.

\begin{tabular}{|c|c|c|c|c|c|c|c|c|c|c|c|}
\hline No & Nama & Q1 & Q2 & Q3 & Q4 & Q5 & Q6 & Q7 & Q8 & Q9 & Q10 \\
\hline 1 & P1 & 1 & 0 & 1 & 1 & 0 & 0 & 0 & 1 & 0 & 0 \\
\hline 2 & P2 & 0 & 0 & 0 & 0 & 0 & 0 & 0 & 1 & 0 & 0 \\
\hline 3 & P3 & 0 & 0 & 0 & 1 & 0 & 0 & 0 & 0 & 0 & 0 \\
\hline 4 & P4 & 1 & 1 & 0 & 0 & 0 & 0 & 0 & 0 & 0 & 0 \\
\hline 5 & P5 & 1 & 0 & 0 & 1 & 0 & 0 & 0 & 0 & 0 & 0 \\
\hline 6 & P6 & 0 & 0 & 0 & 1 & 0 & 0 & 0 & 1 & 0 & 0 \\
\hline 7 & P7 & 0 & 1 & 0 & 0 & 0 & 0 & 0 & 1 & 0 & 0 \\
\hline 8 & P8 & 0 & 0 & 0 & 0 & 0 & 0 & 0 & 1 & 0 & 0 \\
\hline 9 & P9 & 0 & 1 & 0 & 0 & 0 & 0 & 0 & 1 & 0 & 0 \\
\hline 10 & P10 & 0 & 0 & 0 & 0 & 0 & 0 & 0 & 0 & 0 & 0 \\
\hline \multicolumn{2}{|c|}{ Jumlah Jawaban Ya } & 3 & 3 & 1 & 4 & 0 & 0 & 0 & 6 & 0 & 0 \\
\hline \multicolumn{2}{|c|}{ Jumlah Jawaban Tidak } & 7 & 7 & 9 & 6 & 10 & 10 & 10 & 4 & 10 & 10 \\
\hline \multicolumn{2}{|c|}{ Jumlah data } & 10 & Peser & & & & & & & & \\
\hline \multicolumn{2}{|c|}{ Total Jawaban Ya } & 17 & & & & & & & & & \\
\hline \multicolumn{2}{|c|}{ Total Jawaban Yidak } & 83 & & & & & & & & & \\
\hline
\end{tabular}

Tabel 1 merangkan rekapan form quisioner pretest yang sudah diisi oleh peserta pelatihan, dimana sebanyak 17 dijawab peserta yang baru mengetahui berkenaan dengan mawaris dan perhitungan menggunakan android, sedangkan 83 
pertanyaan peserta menjawab Tidak atau peserta yang belum mengetahui tentang mawaris dan menghitung mawaris berbasis android, seperti terlihat pada tabel 2.

Tabel 2. Pesentasi nilai pengetahuan peserta

\begin{tabular}{|c|c|c|c|}
\hline No & Pertanyaan & $\begin{array}{c}\text { Jawab } \\
\text { Ya } \\
\end{array}$ & (\%) Jawaban Ya \\
\hline 1 & Q1 & 3 & 30.0 \\
\hline 2 & Q2 & 3 & 30.0 \\
\hline 3 & Q3 & 1 & 10.0 \\
\hline 4 & Q4 & 4 & 40.0 \\
\hline 5 & Q5 & 0 & 0.0 \\
\hline 6 & Q6 & 0 & 0.0 \\
\hline 7 & Q7 & 0 & 0.0 \\
\hline 8 & Q8 & 6 & 60.0 \\
\hline 9 & Q9 & 0 & 0.0 \\
\hline 10 & Q10 & 0 & 0.0 \\
\hline \multicolumn{2}{|c|}{ Total } & 17 & 170.0 \\
\hline \multicolumn{2}{|c|}{ Rata-Rata } & 1.70 & 17.0 \\
\hline
\end{tabular}

Tabel 2 memperlihatkan jumlah persentasi pengetahuan peserta sebelum dilakukannya pelatihan, dimana peserta baru mengetahui berkenaan dengan mawaris dan perhitungan mawaris menggunakan aplikasi android sebesar $17.0 \%$, berdasarkan aturan rumus quttman berarti pengetahun peserta menghitung mawaris dengan aplikasi android dengan nilai pesentasi $17.0 \%$ adalah mendekati tidak sesuai atau mendekati tidak memahami tentang mawaris.

Tabel 3. Data Posttest pelatihan

\begin{tabular}{|c|c|c|c|c|c|c|c|c|c|c|c|}
\hline No & Nama & Q1 & Q2 & Q3 & Q4 & Q5 & Q6 & Q7 & Q8 & Q9 & Q10 \\
\hline 1 & P1 & 1 & 1 & 1 & 1 & 1 & 0 & 1 & 1 & 1 & 1 \\
\hline 2 & P1 & 1 & 1 & 1 & 1 & 1 & 1 & 1 & 1 & 1 & 1 \\
\hline 3 & P1 & 1 & 1 & 1 & 1 & 1 & 1 & 1 & 1 & 1 & 1 \\
\hline 4 & P1 & 1 & 1 & 1 & 1 & 1 & 1 & 1 & 1 & 1 & 1 \\
\hline 5 & P1 & 1 & 1 & 1 & 1 & 1 & 1 & 1 & 1 & 1 & 1 \\
\hline 6 & P1 & 1 & 1 & 1 & 1 & 1 & 1 & 0 & 1 & 1 & 1 \\
\hline 7 & P1 & 1 & 1 & 1 & 1 & 0 & 0 & 1 & 1 & 1 & 1 \\
\hline 8 & P1 & 1 & 1 & 1 & 1 & 1 & 1 & 0 & 1 & 1 & 1 \\
\hline 9 & P1 & 1 & 1 & 1 & 1 & 1 & 1 & 1 & 1 & 1 & 1 \\
\hline 10 & P1 & 1 & 1 & 0 & 0 & 1 & 1 & 1 & 1 & 1 & 1 \\
\hline \multicolumn{2}{|c|}{ Jumlah Jawaban Ya } & 10 & 10 & 9 & 9 & 9 & 8 & 8 & 10 & 10 & 10 \\
\hline \multicolumn{2}{|c|}{ Jumlah Jawaban Tidak } & 0 & 0 & 1 & 1 & 1 & 2 & 2 & 0 & 0 & 0 \\
\hline \multicolumn{2}{|c|}{ Jumlah data } & 10 & \multicolumn{9}{|c|}{ Peserta } \\
\hline \multicolumn{2}{|c|}{ Total Jawaban Ya } & 93 & & & & & & & & & \\
\hline \multicolumn{2}{|c|}{ Total Jawaban Yidak } & 7 & & & & & & & & & \\
\hline
\end{tabular}

Tabel 3 merangkan rekapan form quisioner posttest yang sudah diisi oleh peserta pelatihan, dimana sebanyak 93 dijawab peserta sudah mengetahui berkenaan dengan mawaris dan perhitungan menggunakan android, sedangkan 7 pertanyaan peserta menjawab Tidak atau peserta yang masih ragu dalam menghitung mawaris berbasis android. Berikut bisa kita lihat tabel persentasinya tingkat pemahaman setelah pelatihan.

\begin{tabular}{cccc}
\multicolumn{4}{c}{ Tabel 4. Persentasi nilai menjawan YA } \\
\hline No & Pertanyaan & Jumlah YA & $\begin{array}{c}(\%) \\
\text { Jawaban } \\
\text { Ya }\end{array}$ \\
\hline 1 & Q1 & 10 & 100.0 \\
2 & Q2 & 10 & 100.0 \\
3 & Q3 & 9 & 90.0 \\
4 & Q4 & 9 & 90.0 \\
5 & Q5 & 9 & 90.0 \\
6 & Q6 & 8 & 80.0 \\
7 & Q7 & 8 & 80.0 \\
8 & Q8 & 10 & 100.0 \\
9 & Q9 & 10 & 100.0 \\
10 & Q10 & 10 & 100.0 \\
\hline Total & & 93 & 930.0 \\
Rata-Rata & & 9.30 & 93.0 \\
\hline
\end{tabular}

Tabel 4 memperlihatkan jumlah persentasi pengetahuan peserta sesudah dilakukannya pelatihan, dimana peserta sudah mengetahui berkenaan dengan mawaris dan perhitungan mawaris menggunakan aplikasi android sebesar $93.0 \%$, berdasarkan aturan rumus quttman berarti pengetahun peserta menghitung mawaris aplikasi android dengan nilai pesentasi 93.0 dimana nilai ini adalah peserta sudah memahami tentang mawaris.

Berdasarkan proses evaluasi pelatihan yang dilakukan dengan skala guttmen dapat diuraikan bahwa tingkat pemahaman peserta sebelum dilakukan pelatihan hanya $17.0 \%$ dimana nilai persentasi ini belum mendekati pemahaman. Sedangkan setelah dilakukannya pelatihan nilai pemahaman peserta meningkat sebanyak $93.0 \%$. Sehingga untuk mendapatkan berapa nilai kenaikan pemahaman peserta dengan cara nilai peserta yang sudah mengikuti pelatihan dengan setelah dilakukan pelatihan. Nilai persentasi peserta yang sudah penah mengikuti pelatihan $93.0 \%$, Nilai persentasi peserta sebelum mengikuti kegiatan pelatihan, sehingga hasinya $76.0 \%$ nilai ini dikatakan mendekati 
kepemahaman. Untuk melihat grafik dapat dilihat pada gambar 8 .

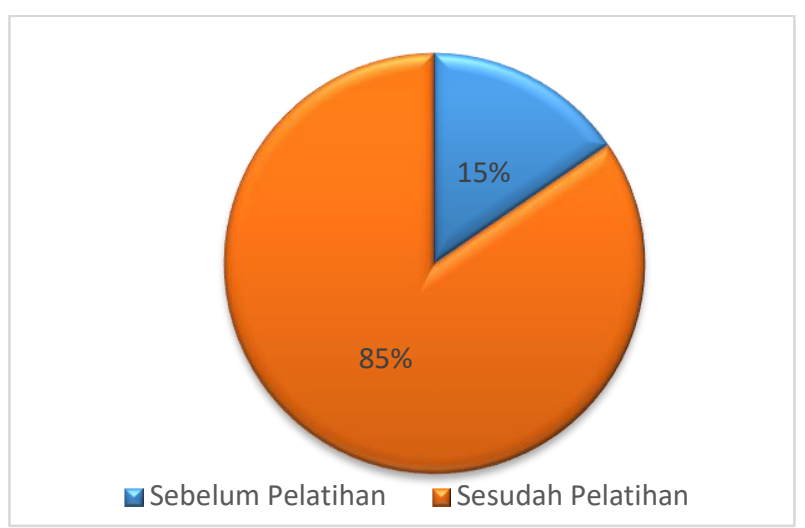

Gambar 8. Grafik tangkat pemahaman `

\section{Ucapan Terima Kasih}

Terimakasih kepada Fakultas Ilmu Komputer Universitas Lancang Kuning yang telah memberikan dana untuk pelaksanaan kegiatan pengabdian masyarakat ini.

\section{PENUTUP}

\section{Kesimpulan}

Dari rangkaian kegiatan program pengadian kepada masyarakat dalam pelatihan menghitung mawaris dengan aplikasi android, dapat disimpulkan sebagai berikut. (1) Bahwa tingkat pemahaman masyarakat masih rendah tentang menghitung seajauh mana masuarakat $17.0 \%$. (2) Bahwa tingkat pemahaman peserta meningkat sebesar $83.0 \%$ setelah mendapatkan pelatihan. (3) Bahwa tingkat kenaikan pemahaman pelajar dalam melakukan pelatihan sebesar $76.0 \%$

\section{Saran}

Berdasarkan hasil evaluasi kegiatan pengabdian kepada masyarakat dapat diberikan saran dengan peningkatan tetang mawaris dan langkah langkah menghitung mawaris, hingga kemampuan menggunakan aplikasi terus bertambah.

\section{DAFTAR PUSTAKA}

Darmawiyah, D. (2017). Strategi Pembelajaran Fiqih Mawaris Pada Dayah Madinatuddiniyah Darul Huda Aloh Gadeng Dan Dayah Terpadu
Madinatuddiniyah Jabal Nur Paloh Lada Di Kabupaten Aceh Utara. Jurnal Ilmiah Didaktika, $\quad 17(2), \quad 245$. https://doi.org/10.22373/jid.v17i2.1642

Guntoro, G., Lisnawita, L., \& Sadar, M. (2019). Pelatihan Internet Sehat dan Aman bagi Siswa SMK Masmur Pekanbaru. Jurnal Pengabdian Pada Masyarakat, 4(2), 223-230. https://doi.org/10.30653/002.201942.105

Huda, A., Fuady, S., \& Muhadi. (2020). Pelatihan Manajemen Masjid Di Masjid Darul Muttaqin Desa Pengandonan Kecamatan Buay Madang Timur Kabupaten Oku Timur. Jurnal Pengabdian Kepada Masyarakat, 1(1), 28-50.

Ismanto, E., Novalia, M., \& Herlandy, P. B. (2017). Pemanfaatan Smartphone Android Sebagai Media Pembelajaran Bagi Guru Sma Negeri 2 Kota Pekanbaru. Jurnal Pengabdian UntukMu NegeRI, 1(1), 42-47. https://doi.org/10.37859/jpumri.v1i1.33

Loneli Costaner, Bayu Febriadi, \& Guntoro. (2020). Pelatihan Dasar Membuat Aplikasi Android App Inventor Pada Sekolah Menengah Atas Saint Siak Sri Indrapura. Dinamisia: Jurnal Pengabdian Kepada Masyarakat, 4(3), 525530. https://doi.org/10.31849/dinamisia.v4i3.4351

Mannuhung, S., Tenrigau, A. M., \& D, D. (2018). Manajemen Pengelolaan Masjid Dan Remaja Masjid Di Kota Palopo. To Maega | Jurnal Pengabdian Masyarakat, 1(1), 14-21.

Mochammad Arif Budiman, \& Mairijani. (2016). Peran Masjid dalam Pengembangan Ekonomi Syariah di Kota Banjarmasin. At-Taradhi: Jurnal Studi Ekonomi, 7(2), 175-182.

Mulyono, M. (2011). Rekonstruksi Peran Dan Fungsi Masjid Sebagai Pusat Kegiatan Pendidikan Islam. MUADDIB:Studi Kependidikan Dan Keislaman, $\quad 7(1)$, 13-32. https://doi.org/10.24269/muaddib.v7n1.2017.1 3-32

Suryadi, A., Nasution, A., \& Febrianti, E. L. (2018). Pengenalan dan Pelatihan Bahasa Pemrograman Andorid Pada Siswa SMK Negeri 1 Air Joman - Kisaran. Jurdimas (Jurnal Pengabdian Kepada Masyarakat ) Royal, 1(2), 2-5. Retrieved from https://jurnal.stmikroyal.ac.id/index.php/jurdi mas/article/view/101

Wahyuni, A. (2018). Sistem Waris Dalam Perspektif Islam dan Peraturan Perundang-undangan Di Indonesia. SALAM: Jurnal Sosial Dan Budaya Syar-I, 5(2), 147-160. https://doi.org/10.15408/sjsbs.v5i2.9412 